\title{
Chemical Composition and Antimicrobial Activity of the Crude Extracts Isolated from Zingiber Officinale by Different Solvents
}

\author{
Hiba Ali Hasan ${ }^{1 *}$, Ayad Mohammed Rasheed Raauf², Basama Monjd Abd Razik² and Bassam Abdul Rasool Hassan ${ }^{3}$
}

${ }^{1}$ Department of Clinical Laboratory Science, College of Pharmacy, Al-Mustansiriya University, Baghdad, Iraq

${ }^{2}$ Department of Pharmaceutical Chemistry, College of Pharmacy, Al- Mustansiriya University Baghdad, Iraq

${ }^{3}$ Clinical Pharmacy Discipline, School of Pharmaceutical Sciences, University of Sains Malaysia, Penang, Malaysia

\begin{abstract}
Background: Since primitive times, man has gone in different ways to search for cures and relief from various diseases by using several plants, plant products and plant-derived products. Recently, there is a scientific curiosity and certain popularity with regard to screening essential oils and extracts from plants used medicinally all over the world.

Objective: This study design to evaluate the component of ginger extracts in different solvents by HPLC in addition to evaluate the in vitro effects of it on micro-organisms, especially the plant is used in Iraqi folk medicine as anti-inflammatory, antipyretic, anti-diabetic, relieving rheumatic pains and for treating stomach discomfort.
\end{abstract}

Methods: The extraction of soluble compounds from ginger by the soxhlet method was performed by using methanol and $n$-hexane as solvents and the main composition of ginger extracts were analyzed by HPLC. Agar well diffusion method tested antimicrobial activities of two crud extracts in different concentrations of plant on seven types of bacteria strains and one fungus.

Results: Seven components were identified from the separation of ginger extracts by HPLC. The two extracts had antimicrobial activity, methanol extract was superior than $n$-hexane extract against the same tested microorganisms.

Conclusion: The results of this study revealed that this plant possesses some antimicrobial properties as antibiotics and antifungal, therefore they can be used as a potential source of active ingredients for food, pharmaceutical industry or preservatives.

Keywords: Zingiber officinale; Chemical composition; Antimicrobial activity; HPLC

\section{Introduction}

Ginger (Zingiber officinale), a member of the Zingiberaceae family, is a well-known spice used in the daily diet in many Asian countries [1]. It is a rhizomatous plant grown throughout South-eastern Asia, China and in parts of Japan, Austria, Latin America, Jamaica and Africa. It has been used as a spice and medicine in India and China since ancient times. It was known in Germany and France in the ninth century and in England in 10th century for its medicinal properties [2].

Over three quarters of the world population still rely on plants and plant extracts for health care [2]. Ginger compounds are active against specific type of diarrhea which is leading to cause death in infant in developing countries. Moreover, it has been found that ginger is effective in treating nausea caused by sea sickness, morning sickness and chemotherapy, though it was found superior over a place for post operative nausea [3]. In addition, it has been reported that the main ingredients of ginger like volatile oil, gingerol, shogaol and diarylheptanoids work as antioxidant, anti-inflammatory, anti-lipid, anti-diabetic, analgesic, antipyretic and anti-tumor [1-11].

Moreover, it is consumed worldwide as flavoring agent which is used extensively in food, beverage, and confectionary industries in the products such as marmalade, pickles, chutney, ginger beer, ginger wine, liquors, and other bakery products [12]. In South India, ginger is used in the production of a candy called Injimurappa meaning ginger candy in Tamil [3].

Currently, there is a growing interest to detect natural compounds characteristics and activities, like plant extracts of herb and spices for the preservation of foods, flavor characteristic and sometimes show antioxidant activity as well as antimicrobial activity [11-13]. This gives the motivation for our present study to focus on ginger.

The aim of this study was to determine the chemical composition and antimicrobial activity for different extracts of ginger by investigating its effects on inhibition of biological activity of bacteria and fungi.

\section{Materials and Methods}

\section{Plant material}

The dry rhizomes of ginger plant were collected from herbs market, pulverized by a mechanical grinder and stored in airtight glass containers in dark until extraction.

\section{Microbial strains}

All microbial strains used in the study are clinical strains, and

*Corresponding author: Hiba Ali Hasan, Department of Clinical Laboratory Science, College of Pharmacy, Al-Mustansiriya University, Baghdad, Iraq, Tel: (+964)-770-2-710-740, E-mail: hibaalichemist@yahoo.com

Received October 09, 2012; Accepted November 12, 2012; Published November 15, 2012

Citation: Hasan HA, Rasheed Raauf AM, Abd Razik BM, Rasool Hassan BA (2012) Chemical Composition and Antimicrobial Activity of the Crude Extracts Isolated from Zingiber Officinale by Different Solvents. Pharmaceut Anal Acta 3: 184. doi:10.4172/2153-2435.1000184

Copyright: (c) 2012 Hasan HA, et al. This is an open-access article distributed under the terms of the Creative Commons Attribution License, which permits unrestricted use, distribution, and reproduction in any medium, provided the original author and source are credited. 
kindly provided by microbiology laboratory in college of pharmacy in (September 2011). They are Gram positive: - Staphylococcus epidermidis, Staphylococcus aureus,

Gram negative: - Klebsiella sp., Escherichia coli, Proteus sp. Enterococcus sp., Pseudomonas fluorescent.

Fungus:-Candida albicans.

\section{Preparation of extraction}

Soxhlet extraction (SE): The extraction of soluble compounds from Zingiber officinale by the soxhlet method was performed by using methanol or $\mathrm{n}$-hexane as a solvent. The soxhlet procedure consisted of ground ginger rhizomes $(30 \mathrm{~g})$ placed inside a thimble loaded into the soxhlet extractor (Gerhardt/Germany). The total extracting time was $(10 \mathrm{hrs}$.), and the total amount of solvent was $(300 \mathrm{ml})$ maintained continuously refluxing over the sample. The solvent assays were performed at solvent boiling temperature. After the extraction the solvent was removed from the solute mixture by reduced pressure with rotary evaporator (Heidolph/Germany).

In order to obtain a completing dry extract, the resultant extracts were transferred to glass dishes and were left in $40^{\circ} \mathrm{C}$ oven for $24 \mathrm{hrs}$. , then they were left at $4^{\circ} \mathrm{C}$ until assessments of their antimicrobial activities.

\section{Antimicrobial activity}

Antibacterial activities of Zingiber officinale extracts were evaluated by means of agar-well diffusion assay [14] with some modifications. Fifteen milliliters of the molten agar $\left(45^{\circ} \mathrm{C}\right)$ were poured into sterile petri dishes $(\varnothing 90 \mathrm{~mm})$. Working cell suspensions were prepared and $100 \mu \mathrm{l}$ was evenly spreaded onto the surface of the agar plates of Mueller-Hinton agar (HIMEDIA, India). Once the plates had been aseptically dried, $6 \mathrm{~mm}$ wells were punched into the agar with a sterile Pasteur pipette. The residual extracts were dissolved in their extracting solvents to yield the final concentration: $50,25,12.5,6.25$ and $3.1 \mathrm{mg} / \mathrm{ml}$ and sterilized by filtration (filter pore size $0.45 \mu \mathrm{m}$ ). Thus, $100 \mu \mathrm{l}$ were placed into the wells and the plates were incubated at $37^{\circ} \mathrm{C}$ for $24 \mathrm{hrs}$. Solvents were used as negative control while antibiotic of streptomycin at the concentration of $10(\mu \mathrm{g} /$ disk $)$ was used as positive control. Antimicrobial activity was evaluated by measuring the diameter of circular inhibition zones around the well. A positive result was defined as an inhibition zone (halo size) of $9 \mathrm{~mm}$ or more appearing around the holes, indicating presence of antibacterial substance in the extracts tested [10]. Tests were performed in triplicate.

\section{Analysis of main constituents of ginger extracts using high performance liquid chromatography (HPLC)}

The main compound were separated on FLC (Fast Liquid Chromatographic) column under the optimum condition, column was phenomenex C-18, $3 \mu \mathrm{m}$ particle size $(50 \times 4.6 \mathrm{~mm}$ I.D) column. Mobile phase was THF (tetrahydrofuran), deionized water acidified with $0.1 \%$ acetic acid $(80: 20 \mathrm{v} / \mathrm{v})$ gradient program from $0 \% \mathrm{~B}$ to $100 \%$ B for 12 minutes. Detection UV set at $282 \mathrm{~nm}$, and flow rate $1.2 \mathrm{ml} /$ min. The separation occurred on liquid chromatography Shimadzu 10 AV-LC equipped with binary delivery pump model LC-10 A-SPD spectrophotometer.

\section{Results}

\section{Chemical composition of the extracts}

Chromatographic analysis by HPLC of the crud extracts allowed the identification of seven main components, in comparison with standard. The major identified components from the terpene family, most of them were sesquiterpene hydrocarbons among them zingiberene $(9 \%, 6 \%), \beta$ - bisabolene $(4 \%, 5 \%), \alpha$-farnesne $(11 \%, 7 \%)$, $\beta$-sesquiphellandrene $(9 \%, 13 \%)$, monoterpene hydrocarbons which is $\alpha$-curcumene $(14 \%, 0 \%)$ and phenolic compounds which are gingerol $(25 \%, 23 \%)$ and shogaol $(18 \%, 25 \%)$ in methanol and $n$-hexane respectively. There is different in the percentage of these components in the two crude extracts according to \% peak area which is illustrated in (Table 1). Chromatograms from the HPLC analysis of the Zingiber officinale extracts are present in Figures 1,2,3 and 4 .

\section{Antimicrobial activity of extracts}

The in vitro antimicrobial activity of the two extracts against the tested bacteria and fungi was assessed in both cases of presence and absence of inhibition zone diameters. We found that the antimicrobial activity of the two extracts i.e., diameter of inhibition zone mainly depend on their concentration and on the strain of tested bacteria and fungi.

So when the methanol used as a solvent, the antimicrobial activity for Zingiber officinale rhizomes extract shown in table 2. Gram-positive bacteria: Staphylococcus epidermidis shows sensitivity to methanol extract concentration ranges from $50-25(\mathrm{mg} / \mathrm{ml})$, and Staphylococcus aureus show sensitivity to concentration ranges from $50-12.5 \mathrm{mg} / \mathrm{ml}$. While, for Gram negative bacteria: Klebsiella sp. and Enterococcus $s p$. show sensitivity to concentration ranges from $50-25 \mathrm{mg} / \mathrm{ml}$, Proteus sp., Escherichia coli and Pseudomonas florescent both shown sensitivity to concentration of $50 \mathrm{mg} / \mathrm{ml}$. Moreover Candida albicans fungi show sensitivity to concentration of $50 \mathrm{mg} / \mathrm{ml}$.

While, the antimicrobial activity for the extract by using n-hexane as a solvent is shown in table 3, Gram-positive bacteria: Staphylococcus epidermidis shows sensitivity to concentration of $50 \mathrm{mg} / \mathrm{ml}$, while Staphylococcus aureus show sensitivity to concentration ranges from $50-25 \mathrm{mg} / \mathrm{ml}$. This extract is also show inhibition activity against Gram-negative bacteria: Proteus sp., Escherichia coli, Enterococcus sp., Pseudomonas florescent all show sensitivity towards $50 \mathrm{mg} / \mathrm{ml}$ concentration. Moreover, this concentration also shows inhibition action against Candida albicans fungi.

But as it is clear from the results when the n-hexane used as a solvent its extract is less effective than methanol extract against the same tested bacteria and fungi.

While, for negative control (solvents) used for preparation different concentrations show no activity against any tested bacteria and fungi. As shown in table 4.

\begin{tabular}{|c|c|c|c|c|}
\hline Seq. & $\begin{array}{l}\text { Identified } \\
\text { components }\end{array}$ & $\begin{array}{l}\text { retention } \\
\text { time (minute) }\end{array}$ & $\begin{array}{l}\text { \% peak area* } \\
\text { (methanol) }\end{array}$ & $\begin{array}{l}\% \text { peak area* } \\
\text { (hexane) }\end{array}$ \\
\hline 1 & gingerol & 1.38 & 25 & 23 \\
\hline 2 & zingiberene & 2.68 & 9 & 6 \\
\hline 3 & $\beta$-bisabolene & 3.61 & 4 & 5 \\
\hline 4 & a-farnesene & 4.29 & 11 & 7 \\
\hline 5 & shogaol & 5.28 & 18 & 25 \\
\hline 6 & $\beta$-sesquiphellandrene & 6.62 & 9 & 13 \\
\hline 7 & a-curcumene & 7.19 & 14 & 0 \\
\hline
\end{tabular}

*Peak area was calculated from area of (sample/total area) $\times 100$

Table 1: Relative composition profile, in \% peak area, of Zingiber officinale extracts. 
<smiles>CCCCC[C@H](O)CC(=O)CCc1ccc(O)c(O)c1</smiles>

(5S)-5-hydroxy-1-(4-hydroxy-3-methoxyphenyl)decan-3-one

(gingerol)

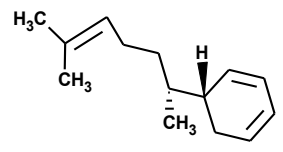

$(5 R)$-5-[(1R)-1,5-dimethylhex-4-en-1-yl]cyclohexa-1,3-diene zingiberene

$\mathrm{H}_{3} \mathrm{C}$

(4S)-1-methyl-4-(5-methyl-1-methylenehex-4-en-1-yl)cyclohexene $\beta$-bisabolene
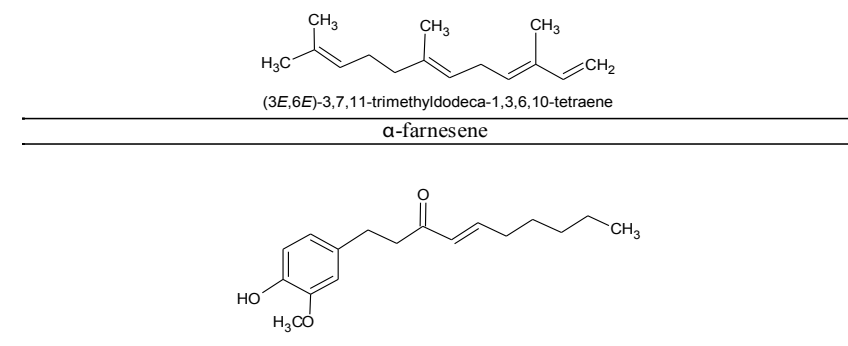

(4E)-1-(4-hydroxy-3-methoxyphenyl)dec-4-en-3-one
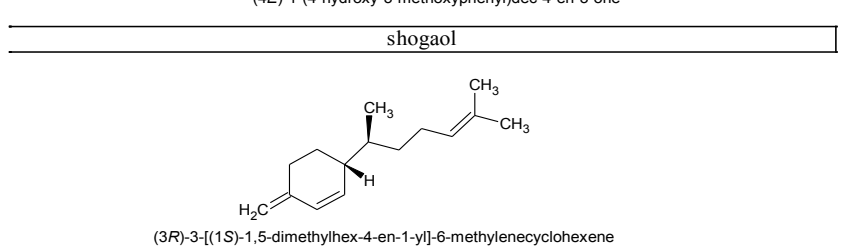

$\beta$-sesquiphellandrene

Figure 1: Chemical structures of the components.

\section{Discussion}

Our present study design to obtain preliminary information on the in vitro antimicrobial activity of Zingiber officinale rhizomes on eight pathogenic micro-organisms, the agar- well diffusion method was preferred to be used in this study, and the two crude extracts were analyzed by HPLC.

The results show that the extraction of ginger by using either methanol or n-hexane has an antimicrobial activity against both bacteria and fungi. This may be caused as a result of the presence of gingerol and shogaol as active ingredient within ginger. Since many studies indicated that the antimicrobial potency of ginger mainly caused by the presence of oxygenated mono- and sesquiterpenes, phenolic compounds (shogaol, gingerol) [15-18], which are lipid-soluble phenol compounds primarily isolated from the root of ginger $[10,19]$.

Bajpai and his colleague also support our explanation that as a result of the presence of mono- and sesquiterpenoids within plant extract, which consider main cause for their antimicrobial mode of action. Since these compounds have different ways of effect since these compounds not only attack cell walls and cell membranes i.e., affecting their permeability and release of intracellular constituents (e.g. ribose, $\mathrm{Na}$ glutamate) but they also interfere with membrane functions (electron transport, nutrient uptake, protein, nucleic acid synthesis and enzyme activity). Thus, these compounds might have several invasive targets which could lead to the inhibition of bacterial pathogens [20].

Moreover, our results show that there is a noticeable difference in the antimicrobial activity of the extract of ginger when the methanol is the solvent than the extract when $n$-hexane is the solvent as seen in

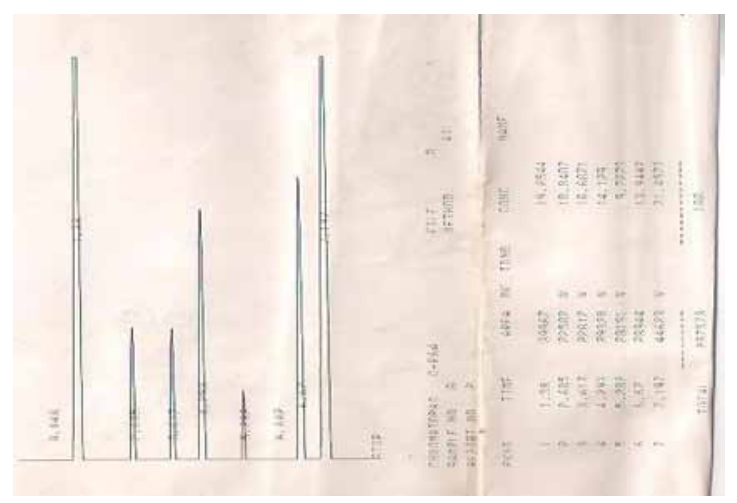

Figure 2: HPLC chromatogram of standard

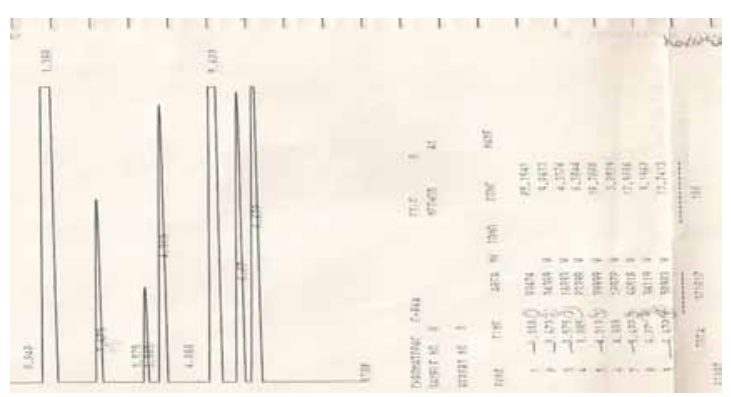

Figure 3: HPLC chromatogram of methanol extract.

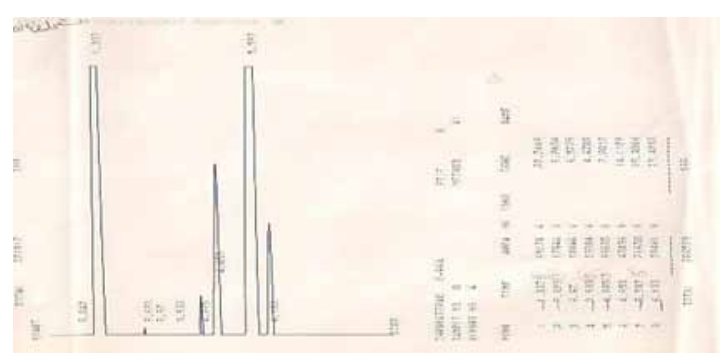

Figure 4: HPLC chromatogram of n-hexane extract. 
Citation: Hasan HA, Rasheed Raauf AM, Abd Razik BM, Rasool Hassan BA (2012) Chemical Composition and Antimicrobial Activity of the Crude Extracts Isolated from Zingiber Officinale by Different Solvents. Pharmaceut Anal Acta 3: 184. doi:10.4172/2153-2435.1000184

table 2 and table 3. There are two points which can help in explanation of this the first point one that as a result of variations in the chemical composition which found between the two ginger extracts i.e., variation related with presence of $\alpha$-curcumene which is monoterpene hydrocarbon within methanol extract but not within n-hexane (Table 1). Chemical variation leads to difference within the antimicrobial activity [18]. While the other point is that because of the difference in concentration of this material i.e., $a$-curcumene between the two extracts this may also leads to differences in the antimicrobial potency, this difference in concentration could be due to the nature of solvent used for extraction [18].

Also the results for both extracts were more effective against the Gram-positive bacteria compared to the results for the Gram-negative ones. The higher resistance of the Gram-negative bacteria could be due to the complexity of the cell wall of this group of microorganisms. Indeed, the external membrane of Gram-negative bacteria renders highly hydrophilic surfaces whereas the negative charge of the surface of the Gram-positive wall may reduce their resistance to antibacterial compounds [15].

\begin{tabular}{|c|c|c|c|c|c|}
\hline \multirow[t]{2}{*}{ Tested micro-organisms } & \multicolumn{5}{|c|}{ Inhibition zone diameter in $(\mathrm{mm})^{\star}$ at different concentrations of methanol extract in $(\mathrm{mg} / \mathrm{ml})$} \\
\hline & 50 & 25 & 12.5 & 6.25 & 3.1 \\
\hline $\begin{array}{l}\text { Gram positive } \\
\text { Staphylococcus epidermidis } \\
\text { Staphylococcus aureus }\end{array}$ & $\begin{array}{l}16.5 \\
17\end{array}$ & $\begin{array}{l}12 \\
16\end{array}$ & - & - & - \\
\hline $\begin{array}{l}\text { Gram negative } \\
\text { Proteus sp. } \\
\text { Klebsiella sp. } \\
\text { Escherichia coli } \\
\text { Enterococcus } s p . \\
\text { Pseudomonas florescent }\end{array}$ & $\begin{array}{l}12.5 \\
14 \\
12 \\
14.5 \\
10\end{array}$ & $\begin{array}{l}- \\
10 \\
- \\
12 \\
-\end{array}$ & $\begin{array}{l}- \\
- \\
- \\
- \\
-\end{array}$ & $\begin{array}{l}- \\
- \\
- \\
- \\
-\end{array}$ & $\begin{array}{l}- \\
- \\
- \\
- \\
-\end{array}$ \\
\hline $\begin{array}{l}\text { Fungi } \\
\text { Candida albicans }\end{array}$ & 13.5 & - & - & - & - \\
\hline methanol (negative control) & - & - & - & - & - \\
\hline
\end{tabular}

*Diameter of inhibition zones including diameter of well $6 \mathrm{~mm}$.

- No inhibition was observed.

Values are given as mean of triplicate experiment

Table 2: Antimicrobial activities of methanol extract of Zingiber officinale rhizomes and methanol (negative control).

\begin{tabular}{|c|c|c|c|c|c|}
\hline \multirow[t]{2}{*}{ Tested micro-organisms } & \multicolumn{5}{|c|}{ Inhibition zone diameter in $(\mathrm{mm})^{*}$ at different concentrations of $\mathrm{n}$-hexane extract in $(\mathrm{mg} / \mathrm{ml})$} \\
\hline & 50 & 25 & 12.5 & 6.25 & 3.1 \\
\hline $\begin{array}{l}\text { Gram positive } \\
\text { Staphylococcus epidermidis } \\
\text { Staphylococcus aureus }\end{array}$ & $\begin{array}{l}18 \\
16.5\end{array}$ & $\overline{-}-$ & - & - & - \\
\hline $\begin{array}{l}\text { Gram negative } \\
\text { Proteus sp. } \\
\text { Klebsiella sp. } \\
\text { Escherichia coli } \\
\text { Enterococcus } s p . \\
\text { Pseudomonas florescent }\end{array}$ & $\begin{array}{l}20.5 \\
- \\
18 \\
15.5 \\
12\end{array}$ & $\begin{array}{l}- \\
- \\
- \\
- \\
-\end{array}$ & $\begin{array}{l}- \\
- \\
- \\
- \\
-\end{array}$ & $\begin{array}{l}- \\
- \\
- \\
-\end{array}$ & $\begin{array}{l}- \\
- \\
-\end{array}$ \\
\hline $\begin{array}{l}\text { Fungi } \\
\text { Candida albicans }\end{array}$ & 14 & - & - & - & - \\
\hline n-hexane & - & - & - & - & - \\
\hline
\end{tabular}

*Diameter of inhibition zones including diameter of well $6 \mathrm{~mm}$.

- No inhibition was observed.

Values are given as mean of triplicate experiment.

Table 3: Antimicrobial activities of $n$-hexane extract of Zingiber officinale rhizomes and $n$-hexane (negative control).

\begin{tabular}{|l|l|}
\hline Tested micro-organisms & Inhibition zone diameter in $\mathbf{( m m})^{*}$ of streptomycin $\left.\mathbf{( 1 0} \boldsymbol{\mu g} / \mathbf{d i s k}\right)$ \\
\hline Gram positive & 21 \\
Staphylococcus epidermidis & 21 \\
Staphylococcus aureus & \\
\hline Gram negative & - \\
Proteus sp. & - \\
Klebsiella sp. & 23 \\
Escherichia coli & - \\
Enterococcus sp. & - \\
\hline Pseudomonas florescent & $* *$ \\
\hline Fungi & \\
\hline Candida albicans &
\end{tabular}

*Diameter of inhibition zones including diameter of well $6 \mathrm{~mm}$.

**nystatin was not tested.

- No inhibition was observed.

Values are given as mean of triplicate experiment

Table 4: Antimicrobial activity of streptomycin (positive control) at concentration of $10(\mu \mathrm{g} / \mathrm{disk})$. 
Citation: Hasan HA, Rasheed Raauf AM, Abd Razik BM, Rasool Hassan BA (2012) Chemical Composition and Antimicrobial Activity of the Crude Extracts Isolated from Zingiber Officinale by Different Solvents. Pharmaceut Anal Acta 3: 184. doi:10.4172/2153-2435.1000184

In addition, the results of antifungal activity assays showed that the two extracts of Zingiber officinale had inhibitory effects on the growth of candeda albicans fungi. Our results are in agreements with previous study in literature mentioned above. The inhibitory effect observed may be a result of monoterpene which is reported to have a wide range of antifungal activity. Since the main mechanism by which will produce its anti-fungal and antimicrobial action through the disruption of bacteria or fungal membrane Integrity [21].

\section{Conclusion}

From the obtained results of our present study we can indicate that ginger extracts have exhibited wide spectrum of antimicrobial properties. Therefore, they can be used for preserving various foodstuffs against microbial spoilage and it can be incorporated into medications for topical antifungal or antibacterial therapy.

\section{References}

1. Demin G, Yingying, Z (2010) Comparative antibacterial activities of crude polysaccharides and flavonoids from Zingiber officinale and their extraction. American Journal of Tropical Medicine 5: 235-238.

2. Sasidharan I, Nirmala Menon A (2010) Comparative Chemical Composition and Antimicrobial Activity Fresh \& Dry Ginger Oils (Zigiber Officinale Roscoe). International Journal of Current Pharmaceutical Research 2: 40-43.

3. Sebiomo A, Awofodu AD, Awosanya AO, Awotona FE, Ajayi AJ (2011) Comparative studies of antibacterial effect of some antibiotics and ginger (Zingiber officinale) on two pathogenic bacteria. Journal of Microbiology and Antimicrobials 3: 18-22.

4. Lee YB, Kim YS, Ahmore CR (1986) Antioxidant property in ginger rhizoma and its application to mate products. Journal of Food Science 51: 20-23.

5. Penna SC, Medeiros MV, Aimbire FS, Faria-Neto HC, Sertié JA, et al. (2003) Anti-inflammatory effect of the hydralcoholic extract of Zingiber officinale rhizomes on rat paws and skin edema. Phytomedicine 10: 381-385.

6. Kadnur SV, Goyal RK (2005) Beneficial effects of Zingiber officinale Roscoe on fructose induced hyperlipidemia and hyperinsulinemia in rats. Indian J Exp Biol 43: 1161-1164.

7. Islam MS, Choi $\mathrm{H}$ (2008) Comparative effects of dietary ginger (Zingiber officinale) and garlic (Allium sativum) investigated in a type 2 diabetes model of rats. J Med Food 11: 152-159.

8. Kim JS, Lee SI, Park HW, Yang JH, Shin TY, et al. (2008) Cytotoxic components from the dried rhizomes of Zingiber officinale Roscoe. Arch Pharm Res 31: 415418.
9. Isa Y, Miyakawa Y, Yanagisawa M, Goto T, Kang MS, et al. (2008) 6-Shogao and 6-gingerol, the pungent of ginger, inhibit TNF-a mediated down regulation of adiponectin expression via different mechanisms in 3T3-L1 adipocytes. Biochem and BiophyS ReS Commun 373: 429-434.

10. Wang W, Li CY, Wen XD, Li P, Qi LW (2009) Simultaneous determination of 6-gingerol, 8-gingerol, 10-gingerol and 6-shogaol in rat plasma by liquid chromatography-mass spectrometry: Application to pharmacokinetics. J Chromatogr B Analyt Technol Biomed Life Sci B 877: 671-679.

11. Shim S, Kim S, Choi DS, Kwon YB, Kwon J (2011) Anti-inflammatory effects of [6]-shogaol: Potential roles of HDAC inhibition and HSP70 induction. Food Chem Toxicol 49: 2734-2740.

12. Wang X, Zheng ZJ, Guo XF, Yuan JP, Zheng CC (2011) Preparative separation of gingerols from Zingiber officinale by high-speed counter-curren chromatography using stepwise elution. Food Chemistry 125: 1476-1480.

13. Tahereh N, Mahsa J (2010) Comparison between Antibacterial Effects of Ethanolic and Isopropyl: Hexan (7:3) Extracts of Zingiber officinale Rose, World Academy of Science. Engineering and Technology 69: 759-762.

14. Yücel G, Çetintas E (2006) Antimicrobial activities of fruits of Crataegus and Pyrus species. Pharmaceutical Biology 44: 79-83.

15. Michielin EM, Salvador AA, Riehl CA, Smânia A Jr, Smânia EF, et al. (2009) Chemical composition and antibacterial activity of Cordia verbenacea extracts obtained by different methods. Bioresource Tech 100: 6615-6623.

16. Elaissi A, Salah K, Mabrouk S, Larbi K, Chemli R (2011) Antibacterial activity and chemical composition of 20 Eucalyptus species' essential oils. Food Chemistry 129: 1427-1434

17. Hossain MA, Shah MD, Sang SV, Sakari M (2011) Chemical composition and antibacterial properties of the essential oils and crude extracts of Merremia borneensis. Journal of King Saud University-Science 24: 243-249.

18. Singh G, Kapoor IP, Singh P, de Heluani CS, de Lampasona MP, et al. (2008) Chemistry, antioxidant and antimicrobial investigations on essential oil and oleoresins of Zingiber officinale. Food and Chem Toxicol 46: 3295-3302.

19. Liu Z (2011) Diterpene Glycosides as Natural Solubilizers. United States Paten Application Publication. Patent Department Taylor, Porter, Brooks \& Philips.

20. Bajpai VK, Al-Reza SM, Choi UK, Lee JH, Kang SC (2009) Chemical composition, antibacterial and antioxidant activities of leaf essential oil and extracts of Metasequioa glyptostroboides Miki ex Hu. Food Chem Toxicol 47: 1876-1883.

21. Deba F, Xuan TD, Yasuda M, Tawata S (2008) Chemical composition and antioxidant, antibacterial and antifungal activities of the essential oils from Bidens pilosa Linn. Var. Radiata. Food Control 19: 346-352. 